\title{
The underutilized terrace wall can be intensified to improve farmer livelihoods
}

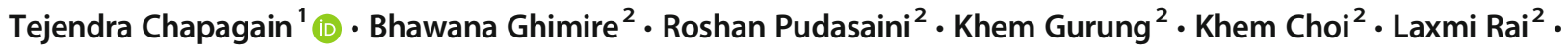 \\ Samjhana Magar $^{2}$ • B. K. Bishnu ${ }^{2} \cdot$ Manish N. Raizada ${ }^{1}$
}

Accepted: 1 April 2019 / Published online: 29 April 2019

(C) INRA and Springer-Verlag France SAS, part of Springer Nature 2019

\begin{abstract}
Millions of vulnerable smallholder farmers around the world cultivate crops on narrow hillside terraces and suffer from inadequate flat growing areas to support their families. A significant amount of surface area on terraces is actually vertical - specifically the underutilized terrace walls (risers). Some indigenous farmers in Nepal have been observed to cultivate wall-climbing and walldescending crops, sown at the base or top edge of the walls, respectively, but these have not been evaluated for their economic benefits and adoption potential. Participatory on-farm trials were conducted on 280 terrace farms in two districts of Nepal (Kaski, Dhading) for two cropping seasons (2015-2016). Three wall-climbing crops (yam in sacks, chayote squash, pumpkin) and four walldescending crops (ricebean, cowpea, horsegram, blackgram) were each grown by 20 farmers per crop per site and evaluated for potential net economic returns and perceptions of all 280 participating women farmers based on five adoption criteria. Here, we show, for the first time to the best of our knowledge, that terrace walls or risers can be intensified with suitable wall-climbing and walldescending crops. All three wall-climbing crops were productive, with potential net economic returns ranging from US \$27 per plant for chayote squash, \$10/plant for pumpkin, and \$2/plant for yam. Similarly, all four wall-descending crops were productive, with potential net economic returns ranging from US $\$ 9-\$ 15$ per $100 \mathrm{~m}$ of wall edge. All the wall crops received good-to-excellent ratings (typically $>8 / 10$ ) by women farmers for simplicity, compatibility, affordability, potential economic returns, and willingness to continue. In terms of long-term adoption, yam, pumpkin, ricebean, and cowpea were ranked the highest, with $>90 \%$ farmers willing to continue each practice. We discuss the potential and constraints of transferring these terrace-intensifying strategies globally.
\end{abstract}

Keywords Terrace wall $\cdot$ Terrace riser $\cdot$ Terrace agriculture $\cdot$ Smallholder $\cdot$ Wall-climbing crop $\cdot$ Wall-descending crop $\cdot$ Chayote squash $\cdot$ Yam $\cdot$ Ricebean $\cdot$ Nepal

\section{Introduction}

Terrace farming is a major source of livelihoods for tens of millions of rural peoples who belong to subsistence farming families living on hillsides and mountains in Asia and the Pacific region (China, India, Philippines, Bhutan, and Nepal),

Electronic supplementary material The online version of this article (https://doi.org/10.1007/s13593-019-0574-2) contains supplementary material, which is available to authorized users.

Tejendra Chapagain

tejendra@uoguelph.ca

1 Department of Plant Agriculture, University of Guelph, Guelph, Ontario N1G 2W1, Canada

2 Local Initiatives for Biodiversity, Research and Development (LI-BIRD), Kaski, Pokhara, Nepal
Central America (Honduras, Guatemala, Mexico), South America (Peru, Ecuador, Bolivia), Middle East (Yemen), and East Africa (Ethiopia, Rwanda, Tanzania) (Chapagain and Raizada 2017). In terrace farming, the steeply sloping hillsides are divided into narrow, graduated steps to facilitate the growth of grain crops, horticultural crops, and fodder (Riley et al. 1990; Chapagain and Raizada 2017). In general, terraces involve three different components: the vertical wall (or riser) which is often bare or covered by natural vegetation; the flat land on top of each terrace where farmers traditionally cultivate field crops; and the narrow, often empty, space at the edge of each terrace which is used as a walking path during intercultural operations and for transportation of inputs and harvested commodities (Chapagain and Raizada 2017).

A limiting constraint of terrace farms is the lack of cultivated land area (Chapagain and Raizada 2017). For example, in Nepal, the average farm size in the hilly region is about 0.77 ha, 
shrinking down to 0.68 ha in the mountains (Adhikary 2004). On terrace farms in the Mid-Hills Region of Nepal, farmers typically cultivate on each main terrace (i.e., flatland on the top) but the wall and edges, which cover a significant amount of the surface area (roughly $>25 \%$ ), are neglected and often remain bare or partially covered by natural vegetation (annual grasses, etc.). Hence, opportunities to intensify terrace agriculture include the use of wall-climbing crops sown at the base (e.g., cucurbit family crops such as gourds, pumpkin, chayote, or perennial grasses such as vetiver) and wall-descending crops sown at the top edge of the risers (e.g., ricebean, napier grass) (Chapagain and Raizada 2017). We previously proposed and discussed criteria for wallclimbing and wall-descending plants including tolerance to wallassociated shading, drought tolerance (since terrace farming systems are typically rainfed), and an ability to fit into the existing cropping system (Chapagain and Raizada 2017).

We have observed that some innovative farmers in Nepal have been growing specific climbing and descending crops on terrace walls, but to the best of our knowledge, these practices have not been systematically evaluated for yield and economic gains, and perhaps as a result, not promoted by agronomists. We suspect similar indigenous practices exist in other terrace agriculture regions of the world. In particular, we have observed a few Nepalese farmers growing climbing chayote squash [Sechium edule (Jacq.) Swartz], also called vegetable pear, at the base of terrace walls. More typically chayote is grown at the base of trees, similar to other local tree climbing crops such as yam (Dioscorea spp.) and pumpkin (Cucurbita pepo L.). We have also observed farmers growing ricebean [Vigna umbellata (Thunb.) Ohwi and Ohasi] at terrace edges from where it descends (trails) down terrace walls. Other leguminous crops such as cowpea [Vigna ungiculata (L.) Walp.], blackgram [Vigna mungo (L.) Hepper], and horsegram [Macrotyloma uniflorum (Lam.) Verdc.] are traditionally grown for household consumption on the flat surfaces, and not currently on terrace walls to the best of our knowledge.

The current literature regarding terrace farming has focused on the flat surfaces of the terraces, with topics ranging from soil erosion (Inbar and Llerena 2000; Wheaton and Monke 2001; Londono 2008), soil and water conservation (Bewket 2007; Engdawork and Bork 2014), land use dynamics (Kammerbauer and Ardon 1999; Gautam et al. 2003), economic benefits and ecological impacts (Liu et al. 2011; Sharda et al. 2015), and sustainability and sensitivity to climate change (Branch et al. 2007); however, research on the effective management of walls and edges using agronomic crops has received considerably less or no attention. The objectives of this study were to systematically evaluate the economic benefits and farmer perceptions of growing different wall-climbing and wall-descending crops in two mid-hill districts of Nepal, namely Dhading and Kaski, for two cropping seasons.

\section{Materials and methods}

\subsection{Study site and climate}

Nepal is a mountainous nation with extensive terrace farming in the mid-hills region (Fig. 1a-c), but it is an economically poor country, ranked 157 out of 187 countries in the UNDP's
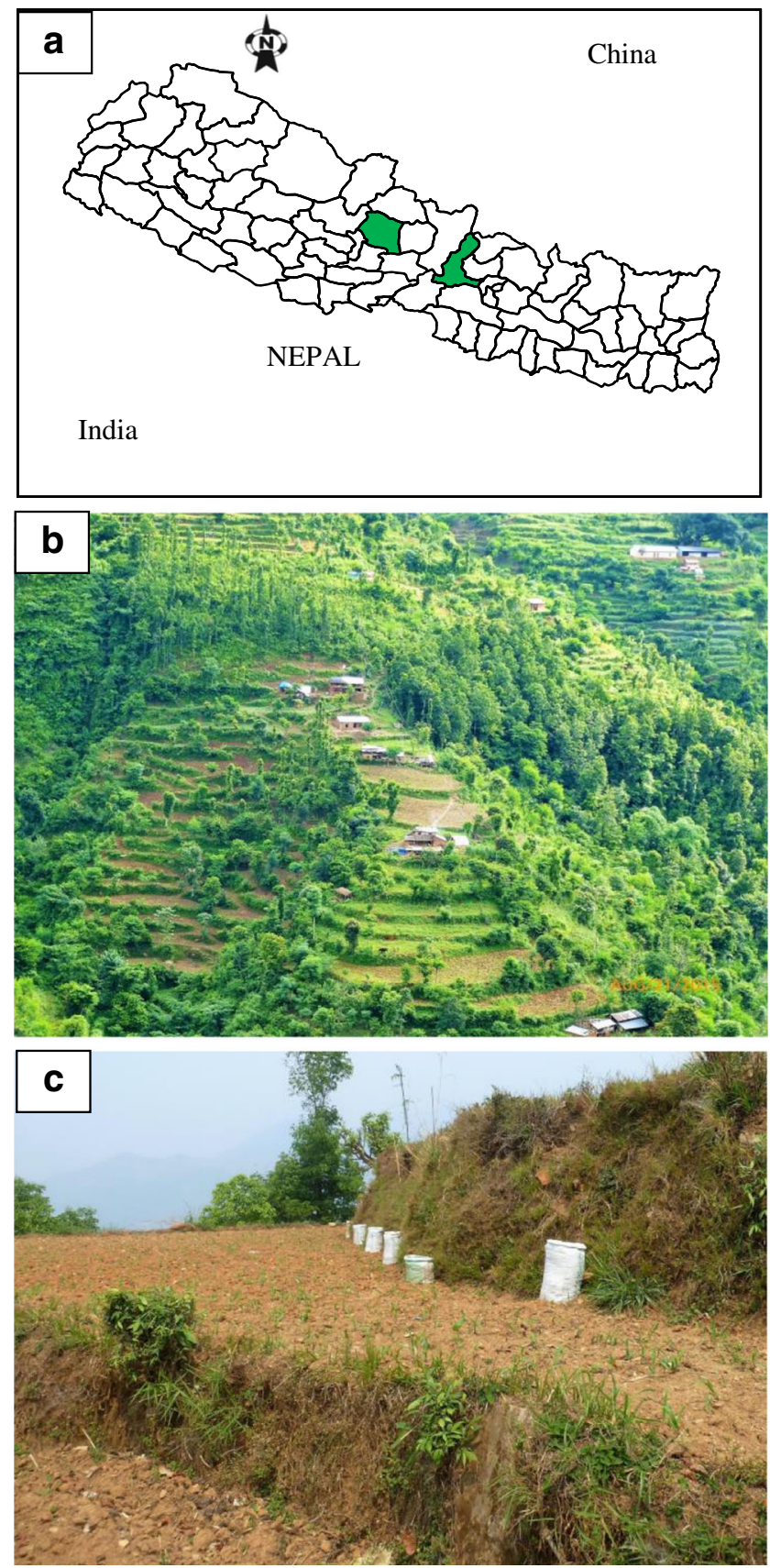

Fig. 1 Study context. a Map of Nepal showing the regions of study: the highlighted areas are the Kaski (left) and Dhading (right) districts. b Example picture of terraces in these districts and the current state of terrace risers. c Close-up of uncultivated traditional terrace wall, left untouched (bottom wall) or used for yam-in-sack cultivation in this study (top wall) 
Human Development Report (IFAD, 2015). More than 30\% of Nepalese people live on less than US \$14 per person, per month (CBS, 2011) with 75\% living below the poverty line in the high hills and mountains (Gartaula et al. 2016). These regions are characterized by highly variable land use systems (e.g., rainfed Bari system in upland and the Khet system in irrigated lowland) (Chapagain et al. 2018). Farmers in both of these regions grow cereals on the main terraces as their staple diet. The major crops grown in the rained Bari system include maize (Zea mays L.), finger millet (Eleusine coracana L.), wheat (Triticum aestivum L.), and/or mustard (Brassica nigra L.) while rice (Oryza sativa L.) is mainly grown in the Khet system. Legumes such as common bean (Phaseolus vulgaris L.), soybean (Glycine max L. Merr.), cowpea, horsegram, blackgram, field pea (Pisum sativum L.), and lentil (Lens culinaris Medik.) are also grown in the upland Bari system depending on the season (Chapagain and Gurung 2010; Wymann von Dach et al. 2013; Chapagain and Raizada 2017).

The experimental sites were located in two mid-hill districts of Nepal (Dhading and Kaski). The Dhading sites were located at $27^{\circ} 78^{\prime} 84^{\prime \prime} \mathrm{N}$ and $84^{\circ} 70^{\prime} 02^{\prime \prime} \mathrm{E}$, at an altitude of $700-1300 \mathrm{~m}$ above sea level (masl) while the sites in Kaski were situated at $28^{\circ} 20^{\prime} 25^{\prime \prime} \mathrm{N}$ and $84^{\circ} 11^{\prime} 71^{\prime \prime} \mathrm{E}$, at an altitude of 1100 masl (Fig. 1a).

Terraces selected for this study were typically $2-3 \mathrm{~m}$ wide (e.g., top wall width), 4-5 m high (e.g., height of the wall), and 50-100 m long across the slopes which make them inappropriate for intensive agriculture. The slope of the terrace walls ranged between 75 and $90^{\circ}$ which often has a greater chance of collapse and requires more maintenance compared to flat terraces. Research was conducted under natural climatic conditions.

Climatic data for the experiment were collected from a regional weather station at the Kaski research site (Fig. 2). Average daytime temperatures over the three cropping seasons (2015-2016: April-July, August-November, and December-March) were $27.8^{\circ} \mathrm{C}, 23.5{ }^{\circ} \mathrm{C}$, and $18.3{ }^{\circ} \mathrm{C}$ in Dhading, and $24.4{ }^{\circ} \mathrm{C}, 21.9^{\circ} \mathrm{C}$, and $16.3^{\circ} \mathrm{C}$ in Kaski with the warmest days in May through August at both sites. Both Dhading and Kaski received more rainfall (annual total of $2660 \mathrm{~mm}$ and $3459 \mathrm{~mm}$, respectively) in 2016, with season 1 (i.e., April-July, 2016) receiving the most (1408 mm and $1758 \mathrm{~mm}$, respectively). Both sites received the least rainfall in the pre-winter/winter season (October through February), receiving no rains in November-December (Fig. 2).

As recently described (Chapagain et al. 2018), the soils in the study area were moderately well-drained coarse textured sandy loam and ranged from low to moderate fertility. At each site, soil samples were collected $(0-20 \mathrm{~cm}$ depth) from farmers' fields at the beginning of trial establishment and analyzed for soil organic matter (SOM) (Walkley-Black method), $\mathrm{pH}$ (using a soil water solution of 1:2.5 wt/v), total $\mathrm{N}$ (modified Kjeldahl method), available P (Bray-P1 method),

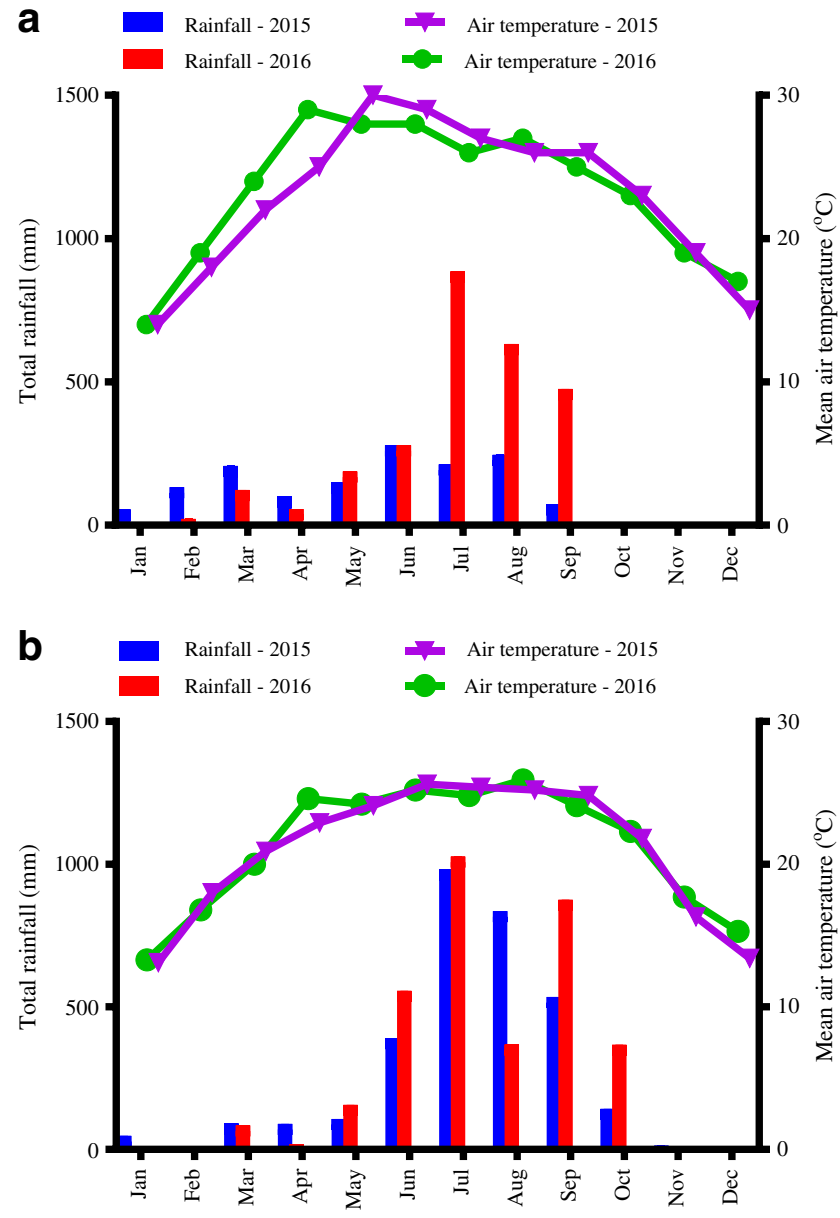

Fig. 2 Climatic data (air temperature and rainfall) collected for a Dhading and $\mathbf{b}$ Kaski districts in 2015 and 2016

and available $\mathrm{K}$ (flame photometer with $1 \mathrm{M}$ ammonium acetate extracting solution) (Anderson and Ingram 1993). The average $\mathrm{SOM}, \mathrm{pH}$, total $\mathrm{N}$, available $\mathrm{P}_{2} \mathrm{O}_{5}$, and $\mathrm{K}_{2} \mathrm{O}$ in Dhading were $32.1 \mathrm{~g} \mathrm{~kg}^{-1}$ dry soil, $6.29,2.2 \mathrm{~g} \mathrm{~kg}^{-1}$ dry soil, $33.5 \mathrm{mg} \mathrm{kg}^{-1}$ dry soil, and $100.6 \mathrm{mg} \mathrm{kg}^{-1}$ dry soil, respectively, whereas these indicators were $39.4 \mathrm{~g} \mathrm{~kg}^{-1}$ dry soil, 5.28 , $2.0 \mathrm{~g} \mathrm{~kg}^{-1}$ dry soil, $44.6 \mathrm{mg} \mathrm{kg}^{-1}$ dry soil, and $101.4 \mathrm{mg} \mathrm{kg}^{-1}$ dry soil in Kaski. The sites were used for grain crop cultivation (maize-millet-beans) in previous years and received low inputs (farm yard manures, chemical fertilizer) and no plant protection chemicals.

\subsection{Selection of wall-climbing and wall-descending crops}

As noted earlier, criteria for selecting wall-climbing and walldescending plants include tolerance to wall-associated shading, drought tolerance for rainfed system, and an ability to fit into the existing cropping system (Chapagain and Raizada 2017). It is important to note that the wall-climbing crops (yam, and two cucurbits: chayote squash and pumpkin) and the wall-descending crops (all legumes: ricebean, cowpea, 
blackgram, horsegram) that we tested in this study in the Dhading and Kaski districts of Nepal were not new to the area. They were all annuals, compatible with the main crop on the flat terraces, and fit well into the cropping calendars. In general, farmers in Nepal grow chayote, yam, and pumpkin at the base of trees, and a few farmers were observed to grow chayote at the base of terrace walls, as noted earlier. This study introduced the concept of growing yam and pumpkin as climbing wall crops. In terms of the leguminous walldescending crops, as noted earlier, some innovative farmers in Nepal already grow ricebean at the terrace edge while cowpea, blackgram, and horsegram are usually grown on the flat surface area of the terraces. Cowpea is typically relayed into maize which is used as a pole crop to facilitate climbing. For blackgram and horsegram, bushy and non-trailing varieties are traditionally grown on flat terraces. Hence, in this study, three of the traditional legume crops grown on the flat terraces were introduced as wall-descending crops. We obtained some trailing varieties with tendrils from local farmers but these were not commercial.

\subsection{Experimental design}

This study involved a randomized complete block design with replication within blocks (locations). There were two blocks (Kaski and Dhading districts). There were seven treatments consisting of three wall-climbing crops (all trailing types such as chayote squash cv. Local Iskush; yam cv. Ban Tarul; and pumpkin cv. Local Pharsi) and four wall-descending crops (ricebean cv. Local Khairo Thulo; horsegram cv. Local Gahat; blackgram cv. Local Kalo Maas; and cowpea cv. Makaibodi), each planted in 20 farmers' fields (replicates) within each block (district). Each farmer tested only one wall-climbing or wall-descending crop; the same farmers tested the same crop in the second year which were annuals, and hence new plants were sown each season. The control plots involved farmers' traditional management, typically fallow; there was native wild vegetation growing out from the walls (see Fig. 1b,c), but this was not removed in any of the treatments.

\subsection{Planting and management details}

For the wall-climbing crops, at least five plants of each crop were planted in each farmer's field, $3 \mathrm{~m}$ apart at the base of a terrace wall. For planting yam, a simple technique was introduced involving planting a healthy seed tuber in a sack (Ghimire et al. 2016), where the sack was filled with soil and farm yard manure (FYM) in a 50:50 ratio and placed at the base of a terrace wall $3 \mathrm{~m}$ apart without deliberate irrigation at the time of transplanting (see Fig. 3a-d). Chayote squash (see Fig. 3e-h) and pumpkin (see Fig. 3i-li-l) were planted in a pit $(0.25 \mathrm{~m} \times 0.25 \mathrm{~m} \times 0.25 \mathrm{~m})$ filled with soil and FYM (50:50).
Yam, chayote, and pumpkins were sown/transplanted in earlyto-mid March in 2015 and 2016.

Similarly, among the four wall-descending crops, ricebean and cowpea were sown in mid-April to mid-May in 2015 and 2016 when maize plants on the flat surface were almost at knee-height; blackgram and horsegram were sown in midJune to mid-July in 2015 and 2016 when finger millet was planted as the primary crop on the flat surface of the terrace. They were dibbled at the top edge of the terraces as one row, $15 \mathrm{~cm}$ apart. In total, there were 4 crops $\times 20$ sites/crop, totalling 80 sites in each district.

No other fertilizers, herbicides, pesticides, or fungicides were used on the walls and risers throughout the growing season. All crops were grown entirely under rainfed conditions.

\subsection{Yield measurements}

For yam, tuber biomass and fresh plant biomass were recorded; for pumpkin, fruit biomass and young shoot biomass were recorded; for chayote squash, the biomass of fruits, shoots and roots/tubers were recorded. For yam, five sacks were harvested per farmer's field to measure tuber yield at maturity. Harvesting was done by cutting or tearing the sacks and removing the tubers by hand. For pumpkin and chayote squash, fruits and shoots were harvested from five plants per farmer's field while they were green (or at horticultural maturity) and continuously harvested until senescence.

For the wall-descending crops, data were recorded for grain and fresh plant biomass yields (kg per $100 \mathrm{~m}$ of wall). For these latter crops, plant and pod color were determinants of maturity, and plants were considered ready for harvest when they were straw-colored and $>80 \%$ of the grains of the pods were in the hard-dough stage. Ten plants in the middle of the terrace edge were harvested at maturity, leaving 5-7 cm stubble, for yield measurements. Seeds were dried under sunlight for 5-7 days, and final seed weight was reported at 13\% moisture content.

\subsection{Economic calculations}

Crops were sold to nearby markets. Gross potential economic returns from the wall-climbing and wall-descending crops were calculated using the average farm gate price of the harvested commodities (tubers, shoots, and grains) based on farmer interviews. Net potential economic returns were calculated as gross potential economic returns less associated expenses involved [calculated as the labor for planting, harvesting, and management; transportation costs (hiring/renting) associated with selling to local markets; seed/planting material cost; and other input costs]. Labor costs were estimated based on the number of hours devoted to each task based on farmer interviews, multiplied by the average local wage (300 NPR/ 
Fig. 3 Example pictures of wallclimbing crops as tested in the Dhading and Kaski districts of Nepal in 2015-2016. a Yam seed tuber ready for planting in a sack. b Yam planted in sacks at the base of two terrace walls. c Chayote plants climbing up a terrace wall. d Chayote fruit ready for harvesting. e Pumpkin shoots climbing up a terrace wall. $\mathbf{f}$ Green pumpkin fruit as a marketable vegetable (most common horticultural maturity stage consumed in Nepal)
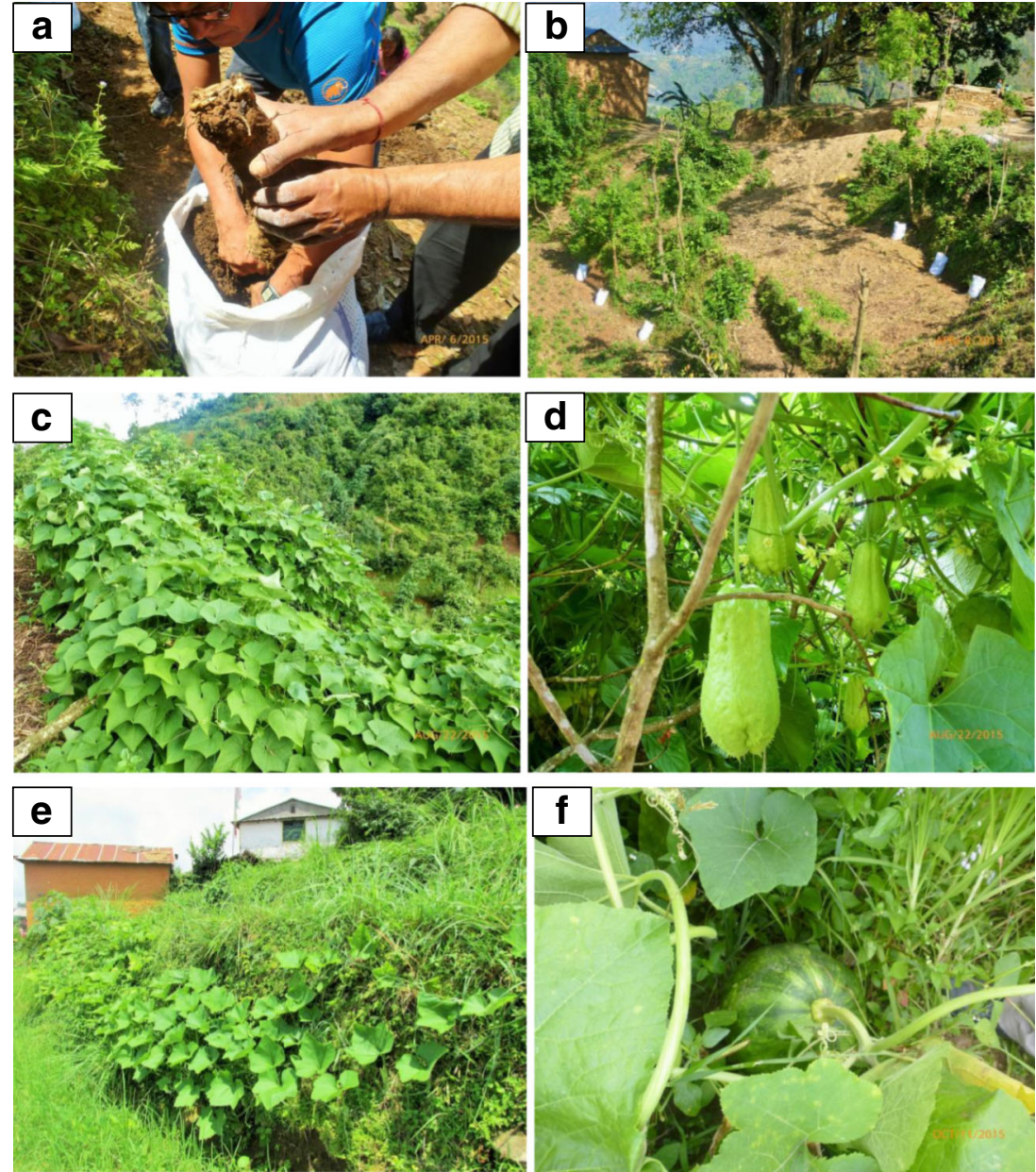

day, equivalent to $\$ 3 \mathrm{USD} /$ day). The transportation cost was calculated as the charge for renting trucks/tractors based on farmers' records. Also considered was the cost of planting materials/seed and equipment where applicable. There were no other input costs (fertilizers, pesticides, etc.).

\subsection{Farmer perception analysis}

This study followed Government of Nepal and University of Guelph ethics guidelines involving human participants. The study was approved by the University of Guelph Ethics Research Committee (REB \#15NV037). Post-trial, 20 participating women farmers per crop per site (total 280 farmers) were surveyed as to their perceptions of the crop interventions.

Only women farmers were selected due to the outmigration of male heads of families or their engagement in non-farm occupations which leaves women responsible for terrace cultivation and maintenance in Nepal (Gartaula et al. 2016). Based on demographic survey information, women were selected that were mostly illiterate (never attended school or had received elementary education), poor (earning $<\$ 1 \mathrm{USD} /$ day), belonged to a diversity of local ethnic groups, and were aged 30-55 years.

Participants were assembled into small groups, and then female LI-BIRD staff interviewed individual farmers verbally. The farmers were asked to rate the climbing and descending crops based on five criteria: simplicity (in terms of usage/understanding), compatibility (i.e., level of competition with the main crop on the flat surface of the terrace), affordability (i.e., cost of seeds and planting materials), potential economic returns (i.e., gross potential income less expenses), and willingness to continue (i.e., longer-term adoption). Farmers rated each criterion on a 0 to 10 scale in which 0 indicated the lowest rating and 10 indicated the highest rating (most positive perception).

\subsection{Statistical analysis}

The data were analyzed using GraphPad Prism 7 software (GraphPad Software, Inc. CA, USA). In order to measure the effects of specific treatments (i.e., climbing or descending crop) on economic costs and returns, the data were aggregated across years and blocks (locations), and analyzed as a 
randomized complete block design with 20 replications (farmer's field) within each block (district) using analysis of variance (ANOVA) set at $p<0.05$. Crop was the treatment level, and yield, costs, and returns were the measurements.

\section{Results and discussion}

\subsection{Results}

\subsubsection{Wall-climbing crops}

Table 1 shows average yield (e.g., fruit, tuber, shoots) and potential net economic return from chayote squash, pumpkin, and yam in the Dhading and Kaski districts over two cropping seasons in 2015-2016. Among the three climbing crops tested, chayote squash appeared to be highly prolific, producing a substantial amount of fruit and tuber per plant (average of $166 \mathrm{~kg}$ and $16 \mathrm{~kg}$, respectively) with a statistically greater net potential income of \$27 USD per plant to farmers compared to pumpkin and yam (Table 1). Pumpkin produced an average of $52 \mathrm{~kg}$ of fruits per plant and $6 \mathrm{~kg}$ of edible shoots per plant across sites and seasons with a net potential economic return of $\$ 10$ USD per plant (Table 1). Cultivation of yam in sacks, which was introduced as an innovative practice, showed an average yield of $7 \mathrm{~kg}$ of tuber per plant across sites and seasons, providing farmers with a potential net economic income of \$2.40 USD per plant (Table 1). In terms of the block (location) effect, it was statistically significant for chayote squash only, with a net potential income of \$33 USD per plant (average of $210 \mathrm{~kg}$ fruits per plant) in Dhading compared to $\$ 21$ USD per plant (average of $123 \mathrm{~kg}$ fruits per plant) in Kaski across two cropping seasons (Table 1).

\subsubsection{Wall-descending crops}

Among the four wall-descending crops tested, ricebean appeared to be productive across locations and seasons (average grain yield $15.6 \mathrm{~kg}$ per $100 \mathrm{~m}$ of wall, and average shoot biomass $52.9 \mathrm{~kg}$ per $100 \mathrm{~m}$ of wall) which was numerically followed by cowpea (average of $12 \mathrm{~kg}$ of grain and $40 \mathrm{~kg}$ of shoot biomass per $100 \mathrm{~m}$ of wall), horsegram (average of $10 \mathrm{~kg}$ of grain and $39 \mathrm{~kg}$ of shoot biomass per $100 \mathrm{~m}$ of wall), and blackgram (average of $10 \mathrm{~kg}$ of grain and $36 \mathrm{~kg}$ of shoot biomass per $100 \mathrm{~m}$ of wall). In terms of the average net potential economic return across seasons and locations (blocks), ricebean, cowpea, and blackgram were statistically the most valuable at $\$ 15, \$ 14$, and $\$ 13$ USD per $100 \mathrm{~m}$ of wall, respectively, compared to horsegram (\$9 USD per $100 \mathrm{~m}$ of wall) (Table 1). Also, the block (location) effect was significant for all wall-descending crops, with higher net potential economic returns in Kaski compared to Dhading across two cropping seasons, amounting to $\$ 20$ USD per $100 \mathrm{~m}$ of wall for ricebean and cowpea, \$15 USD per $100 \mathrm{~m}$ of wall for blackgram, and \$11 USD per $100 \mathrm{~m}$ of wall for horsegram in Kaski (Table 1).

\subsubsection{Women farmer perception analysis}

Table 2 shows the perception ratings of the wall-climbing and wall-descending crops based on interviews with women farmers who participated in the trials $(n=20$ farmers per crop per district). In general, all the climbing and descending crops received good-to-excellent ratings (typically $>8 / 10$ ) at both sites for simplicity, compatibility, affordability, potential economic returns, and adoption. In terms of the critical criteria of long-term adoption, yam, pumpkin, ricebean, and cowpea received the highest ratings, with $>90 \%$ farmers willing to continue each practice (Table 2). The choice of crop was affected by location; for example, farmers in Dhading preferred chayote squash compared to Kaski, while ricebean was favored by farmers in Kaski compared to Dhading.

\subsection{Discussion}

Our systematic evaluation of these seven crops demonstrates significant economic advantages from planting any of these crops on the terrace walls (risers) compared to uncultivated vertical slopes. Among the three wall-climbing crops tested, chayote squash was potentially the most valuable, whereas ricebean and cowpea were the most valuable among the four wall-descending crops. Furthermore, the 280 women farmers (20 for each crop in each district) who participated in the trials highly rated these wall crops and gave 7/10-9.8/10 scores in terms of their willingness to continue/adopt the practice(s) of growing these crops along terrace walls. The addition of this novel cropping system has intensified the total crop yield and diversity of crops on terrace farms.

\subsubsection{Factors affecting net economic return variation}

Among the wall-climbing crops, we observed greater net economic return from chayote squash in Dhading compared to Kaski which could perhaps be associated with the higher yield of this crop in Dhading. Compared to Kaski, Dhading has sloping risers, which from our observations, are more suitable for growth and production of this crop.

By contrast, we observed statistically greater potential net economic returns for wall-descending crops in Kaski compared to Dhading, which was perhaps associated with the greater yields of these crops and higher farm-gate price of harvested grains in Kaski compared to Dhading. Better growth and production of wall-descending crops in Kaski may have been associated with the higher rainfall recorded there compared to Dhading (Chapagain et al. 2018) as well as the comparatively flatter terraces at that site which favor these crops, 


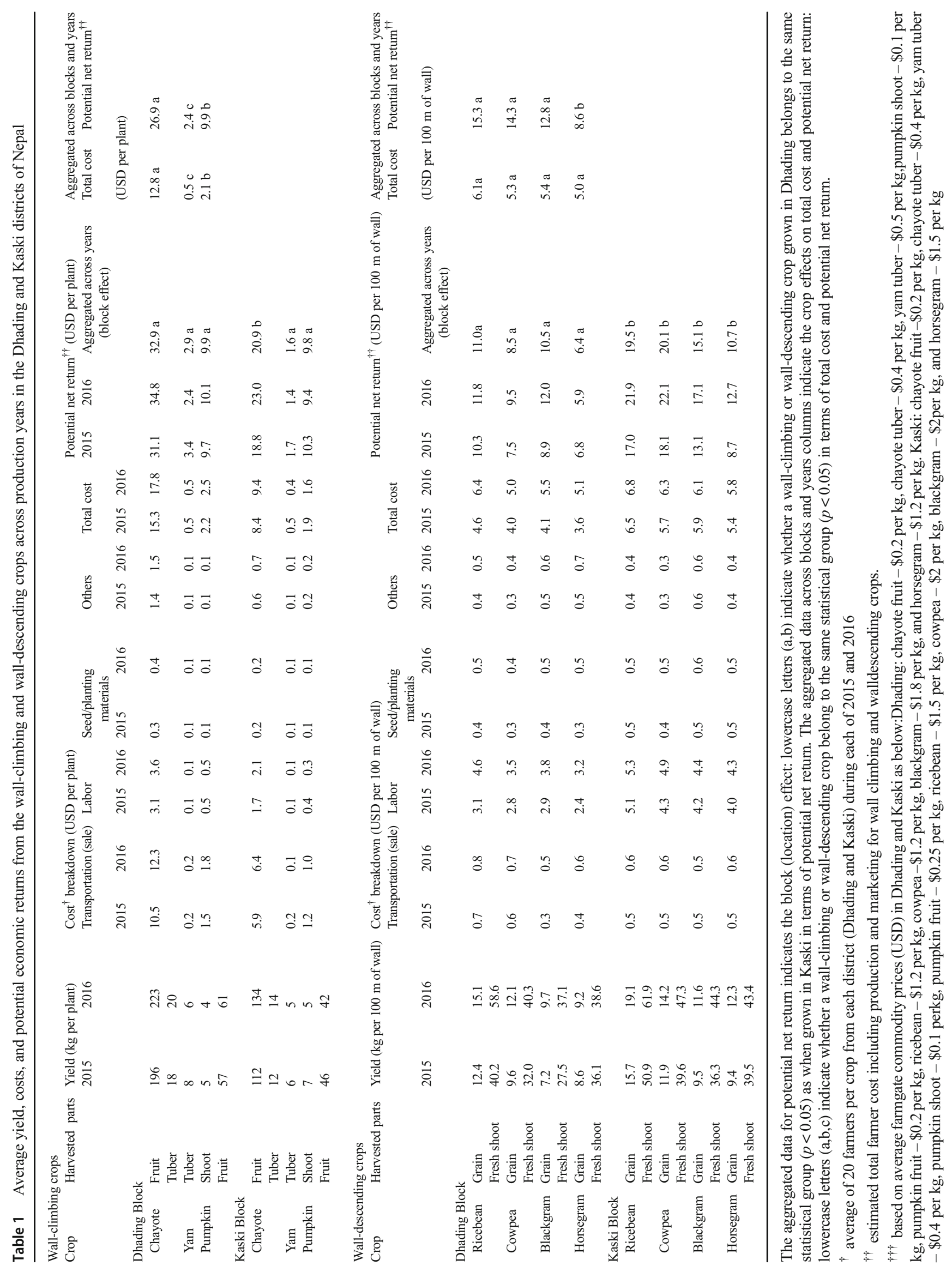


resulting in more sunshine and irrigation water during the growing season.

\subsubsection{Determinants underlying the adoption of specific wall-climbing and wall-descending crops}

Among the crops tested in this study, some were more/less profitable or attractive to the trial farmers than others. For example, in our experience with chayote squash, regardless of the greater potential economic returns associated with this crop, farmers in both trial sites gave it lower ratings compared to yam or pumpkin, primarily because of the high transportation cost (in general, $\sim 70 \%$ of the total cost) to sell chayote fruits and tubers, which are large and heavy, from remote hillside farms (please refer to Table 1). Therefore, it is important that growers find potential marketing channels/outlets and strengthen the marketing network prior to adopting wallgrowing chayote squash for commercial production. Opportunities for processing the excess fruits (e.g., for chips, sauce, etc.) or storing them in low-cost storage structures also need to be explored. Other challenges associated with chayote squash on terrace walls included uncontrolled/prolific vegetative growth which has the potential to compete with the main crop on the flat terraces; this can be controlled by appropriate pruning or by planting chayote squash as a sole crop on fallow terraces which are increasingly prevalent in Nepal, in part due to abandonment associated with male outmigration (Gartaula et al. 2016).

For yam and pumpkin, with the low volume of production per plant, the harvested tubers and fruits are mostly consumed locally at the village level. Hence, transportation costs were not a major constraint. Furthermore, growing yams in sacks eased the labor, typically performed by women, of harvesting yam tubers which involves digging into the soil-the most drudgerous task associated with yam production which limits its production (Ghimire et al. 2016; Chapagain and Raizada 2017). With respect to pumpkin, in our experience, we observed that farmers were unaware of the nutritional value of the seeds which are widely consumed as a staple food crop elsewhere (e.g., pepita in Latin America) (Lira and Caballero 2002; Achu et al. 2005).

For the wall-descending legume crops in this study, transportation costs were low (10\% of the total cost) due to the fact that they are low volume, high value commodities. However, the associated labor costs were very high (in general, $75 \%$ of the total cost, please refer to Table 1) as these crops required labor for manual planting, harvesting, and post-harvest operations. Currently, there exists very limited opportunities for farm mechanization of these crops in the mid-hills of Nepal except for the use of a jab planter, a hand tool for conveniently planting legumes at the top edge of the terraces.

\subsubsection{Importance and challenges of growing wall-climbing and wall-descending crops}

Maintenance of terrace walls is a major issue in terrace agriculture particularly due to the steepness and sparse vegetation of the walls (Lasanta et al. 2001; Van Dijk and Bruijnzeel 2003). Many terrace walls are not vertical but angled; hence, with the wall-climbing and walldescending cropping strategies evaluated here, their canopies should protect the sloped terrace walls against monsoon rainfall thus minimizing soil erosion. We did not remove the native vegetation (e.g., grasses) which may have protected the soil prior to crop root and canopy establishment. Compared to the cereals traditionally grown near the upper terrace edge, the legume descending crops are bushy and hence would form a more protective canopy. Furthermore, these legumes are planted from midApril through mid-July, at the critical onset of the monsoon season (from the dry season) when peak erosion occurs (Bookhagen 2010), and hence, an anticipated benefit of these wall-descending crops is erosion control. Furthermore, if the root system of a wall-climbing or wall-descending crop is fibrous, it would hold soil at the edge and furthermore protect the wall from seepage.

In addition to the above direct/tangible economic benefits, there may be some intangible benefits that the above wall-climbing and wall-descending crops offer to farmers including the environmental benefits already noted (protection of walls/reduced surface run-off and soil erosion) as well as increasing crop diversification to build resiliency and improve overall land productivity. Furthermore, the young and tender leaves of the wall-climbing crops (especially chayote and pumpkin) can be used as green vegetable sources, and additionally, the plant biomass and excess fruits can be used as fodder/feed, to provide associated nutritional benefits (e.g., high fiber, potassium, iron, calcium, vitamin $\mathrm{C}$, essential missing amino acids from legumes) particularly for women and children.

Regardless of a number of benefits associated with these wall-climbing and wall-descending crops, the practice of growing them along terrace walls is not more widespread globally. Some potential reasons could be (1) lack of appropriate trailing varieties as noted above, (2) lack of knowledge of the practices or their benefits, (3) fear of shading the main terrace crop, (4) potential water and nutrient competition with the main terrace crop, and (5) the direction that a slope faces which could be critical in terms of shading by the terrace wall and determinative of the number of hours of daily sunlight received during a growing season.

It is important to reiterate that native wild vegetation is present along terrace walls, which is sometimes used as a forage source locally; this was kept in our treatments but 
Table 2 Perceptions of participating women farmers of different climbing and descending crops in Dhading and Kaski districts of Nepal

\begin{tabular}{|c|c|c|c|c|c|}
\hline Crop & Simplicity & Compatibility & Affordability & Increased income & Willing to continue \\
\hline \multicolumn{6}{|l|}{ Dhading } \\
\hline \multicolumn{6}{|c|}{ Wall-climbing crops } \\
\hline Chayote squash & 9.7 & 8.3 & 9.6 & 9.5 & 7.9 \\
\hline Yam & 9.2 & 9.1 & 9.8 & 8.3 & 9.7 \\
\hline Pumpkin & 9.4 & 9.4 & 9.6 & 8.1 & 9.8 \\
\hline \multicolumn{6}{|c|}{ Wall-descending crops } \\
\hline Ricebean & 9.2 & 8.7 & 9.4 & 9.0 & 9.0 \\
\hline Horsegram & 9.1 & 8.8 & 9.2 & 8.3 & 7.7 \\
\hline Cowpea & 9.1 & 9.2 & 9.3 & 8.7 & 9.5 \\
\hline Blackgram & 9.2 & 9.1 & 9.5 & 8.4 & 7.8 \\
\hline \multicolumn{6}{|l|}{ Kaski } \\
\hline \multicolumn{6}{|c|}{ Wall-climbing crops } \\
\hline Chayote squash & 9.2 & 8.6 & 9.4 & 9.0 & 7.0 \\
\hline Yam & 9.3 & 8.7 & 9.3 & 8.1 & 9.5 \\
\hline Pumpkin & 9.4 & 9.2 & 9.7 & 8.0 & 9.6 \\
\hline \multicolumn{6}{|c|}{ Wall-descending crops } \\
\hline Ricebean & 9.3 & 8.6 & 9.5 & 8.7 & 9.7 \\
\hline Horsegram & 9.0 & 8.4 & 9.2 & 7.6 & 7.4 \\
\hline Cowpea & 9.4 & 9.3 & 9.5 & 8.4 & 9.6 \\
\hline Blackgram & 8.6 & 8.7 & 9.2 & 7.4 & 7.5 \\
\hline
\end{tabular}

Average of 20 women farmers per crop per site based on a $0-10$ rating scale, in which 0 indicates a low preference and 10 indicates high preference would have been suppressed by the crop canopies. As an additional potential adoption constraint, we have observed that farmers in Nepal usually leave some space fallow at the top edge of the terrace to walk and perform intercultural operations (primarily weeding, harvesting, etc.) but they do not use this space often and hence converting the space for planting of the wall-descending crops seems reasonable. For the wall-climbing crops, farmers do cultivate near the base (which is otherwise occupied by the main terrace crop), but these wall-climbing crops occupy a very narrow space so there may be limited detrimental effects on the growth and yield of the main crop. In fact, since farmers use the base or edge for planting these crops, these agronomic strategies take advantage of a terrace wall's sunlight harvesting potential. Furthermore, any unwanted growth of the climbing and descending crops can be controlled by pruning, as noted earlier. In terms of nutrient/water competition, the wall-descending crops evaluated in this study are nitrogen fixers; hence, they contribute nitrogen to the system but they might be consuming other nutrients. Similarly, climbing crops such as chayote and pumpkin might be competing with the main terrace crop for nutrients.

This study focused on evaluating the gains achieved from using the walls, but future studies are needed to evaluate the impacts on the main terrace crops, but it is important to note that the women farmers surveyed very positively viewed these interventions. For wider adoption of the wall-climbing and wall-descending crops, new varieties may need to be tested with an emphasis on tendril varieties which can easily climb and trail across the walls, and provide less impact on the main crops growing on the flat surface of the terraces.

Above all, the potential economic returns associated with the wall-climbing and wall-descending crops, along with women farmer perception data, showed that they hold promise for wider adoption in the mid-hills of Nepal in order to intensify terrace agriculture. Furthermore, these practices/crops hold potential for other terrace regions of the world where these crops are already consumed. In addition, the yam in sack concept, which we introduced for the first time, saves considerable female labor at harvesting, can be transferred globally to flatlands (e.g., by placing the sacks along homestead walls) including in yam growing regions of the world such as subSaharan Africa and the Caribbean.

\section{Conclusion}

This study provided farmers with seven crop options and associated agronomic strategies to better utilize terrace walls/ risers based on local needs and markets. Based on a two- 
season study, here we demonstrated that planting appropriate wall-climbing crops (chayote squash, yam, pumpkin) and wall-descending crops (ricebean, cowpea, blackgram, horsegram) on terrace walls/risers can enhance land productivity and potential economic returns to farmers as they provide additional crop(s) to complement the main terrace crops in the hilly regions of Nepal. There are some challenges for widespread adoption of these wall-climbing and walldescending crops which may require additional studies. Nevertheless, such wall-based intensification is a promising ecological practice for smallholder terrace agriculture on hillsides and mountains where on-farm mechanization is already constrained by the topology and where agriculture is already reliant upon animal and human labor. Effective dissemination and adoption of wall-climbing and wall-descending crops will require potential marketing channels/outlets for highly prolific crops such as chayote squash as well as participatory trials to inform and learn from farmers about their advantages with respect to land productivity, erosion control, soil fertility management, and profit, but also potential constraints. Such strategies could be supported by formalized government policies to diversify terrace agriculture and support for organizations dedicated to the well-being of terrace farmers and ecosystems.

Acknowledgements We thank the leadership and dedicated staff of our SAKNepal partners, LI-BIRD and Anamolbiu, for their agronomic research with terrace farmers that remains a source of inspiration for the authors.

Funding information This study is financially supported by the Canadian International Food Security Research Fund (CIFSRF), jointly sponsored by the International Development Research Centre (IDRC, Ottawa) and Global Affairs Canada (GAC).

\section{Compliance with ethical standards}

Conflict of interest The authors declare that they have no conflict of interest.

\section{References}

Achu MB, Fokou E, Tchiégang C, Fotso M, Tchouanguep MF (2005) Nutritive value of some Cucurbitaceae oilseeds from different regions in Cameroon. Afr J Biotechnol 4(11):1329-1334 Available: https://www.ajol.info/index.php/ajb/article/view/71373. Accessed 27 July 2018

Adhikary, S.K. (2004). Nepal Country Paper. in Technical advisory committee (TAC) and governing board meeting of Asia and the Pacific centre for agricultural engineering and machinery (APCAEM), Hanoi, Vietnam

Anderson, J.M., and Ingram, J.S.I., (eds.). 1993. Tropical soil biology and fertility: a handbook of methods. UK: CAB International (ISBN: 0 $851988210)$

Bewket W (2007) Soil and water conservation intervention with conventional technologies in northwestern highlands of Ethiopia: acceptance and adoption by farmers. Land Use Policy 24:404-416. https://doi.org/10.1016/j.landusepol.2006.05.004
Bookhagen B (2010) Appearance of extreme monsoonal rainfall events and their impact on erosion in the Himalaya. Geomat Nat Haz Risk 1(1):37-50. https://doi.org/10.1080/19475701003625737

Branch NP, Kemp RA, Silva B, Meddens FM, Williams A, Kendall A, Pomacanchari CV (2007) Testing the sustainability and sensitivity to climatic change of terrace agricultural systems in the Peruvian Andes: a pilot study. J Archaeol Sci 34:1-9. https://doi.org/10. 1016/j.jas.2006.03.011

CBS (Central Bureau of Statistics). (2011). Nepal living standard survey. National Planning Commission Secretariat, p. 6. Kathmandu: Government of Nepal

Chapagain T, Gurung GB (2010) Effects of integrated plant nutrition management (IPNM) practices on the sustainability of maize based hill farming systems in Nepal. J Agric Sci 2(3):1-7. https://doi.org/ $10.5539 /$ jas.v2n3p26

Chapagain T, Raizada MN (2017) Agronomic challenges and opportunities for smallholder terrace agriculture in developing countries. Front Plant Sci 8:331. https://doi.org/10.3389/fpls.2017.00331

Chapagain T, Pudasaini R, Ghimire B, Gurung K, Choi KR, Rai L, Magar S, Bishnu BK, Raizada MN (2018) Intercropping of maize, millet, mustard, wheat and ginger increased land productivity and potential economic returns for smallholder terrace farmers in Nepal. Field Crop Res 227:91-101. https://doi.org/10.1016/j.fcr.2018.07.016

Engdawork A, Bork H (2014) Long-term indigenous soil conservation technology in the Chencha area, southern Ethiopia: origin, characteristics, and sustainability. Ambio 43:932-942. https://doi.org/10. 1007/s13280-014-0527-6

Gartaula H, Patel K, Johnson D, Devkota R, Khadka K, Chaudhary P (2016) From food security to food wellbeing: examining food security through the lens of food wellbeing in Nepal's rapidly changing agrarian landscape. Agric Hum Values 34(3):573-589. https://doi. org/10.1007/s10460-016-9740-1

Gautam AP, Webb EL, Shivakoti GP, Zoebisch MA (2003) Land use dynamics and landscape change pattern in a mountain watershed in Nepal. Agric Ecosyst Environ 99:83-96. https://doi.org/10. 1016/S0167-8809(03)00148-8

Ghimire B, Dhakal R, Pudasaini R, Devkota R, Chaudhary P (2016) Yam on terrace walls. LEISA (Low External Input Sustainable Agriculture) 18:23-25 Available: http://www.indiaenvironmentportal.org.in/files/ file/Yam\%20cultivation.pdf. Accessed 27 July 2018

IFAD (International Fund for International Development). (2015). Enabling poor rural people to overcome poverty in Nepal. Available: http://www.ifad.org/operations/projects/regions/pi/ factsheets/nepal.pdf. Accessed 27 July 2018

Inbar M, Llerena C (2000) Erosion processes in high mountain agricultural terraces in Peru. Mt Res Dev 20(2):204-204, 79. https:// doi.org/10.1659/0276-4741(2000)020[0072:EPIHMA]2.0.CO;2

Kammerbauer J, Ardon C (1999) Land use dynamics and landscape change pattern in a typical watershade in the hillside region of central Honduras. Agric Ecosyst Environ 75(1-2):93-100. https://doi. org/10.1016/S0167-8809(99)00071-7

Lasanta T, Arnaez J, Oserin M, Ortigosa LM (2001) Marginal lands and erosion in terraced fields in the Mediterranean mountains. Mt Res Dev 21(1):69-76. https://doi.org/10.1659/0276-4741(2001)021[0069: MLAEIT]2.0.CO;2

Lira R, Caballero J (2002) Ethnobotany of the Mexican Curcubitaceae. Econ Bot 56(4):380-398. https://doi.org/10.1663/00130001(2002)056[0380:EOTWMC]2.0.CO;2

Liu X, He B, Li Z, Zhang J, Wang L, Wang Z (2011) Influence of land terracing on agricultural and ecological environment in the loess plateau regions of China. Environ Earth Sci 62(4):797-807. https://doi.org/10.1007/s12665-010-0567-6

Londono AC (2008) Pattern and rate of erosion inferred from Inca agricultural terraces in arid southern Peru. Geomorph. 99:13-25. https:// doi.org/10.1016/j.geomorph.2007.09.014 
Riley KW, Mateo N, Hawtin GC, Yadav R (1990) Mountain agriculture and crop genetic resources (eds.). Proceeding of international workshop on mountain agriculture and crop genetic resources, Feb 1619, 1987, Kathmandu. HMG Nepal, International Development Research Centre (IDRC), and International Centre for Integrated Mountain Development (ICIMOD). p. 329. Oxford and IBH Publishing Co. Pvt. Ltd., New Delhi

Sharda VN, Dogra P, Sena DR (2015) Comparative economic analysis of inter-crop based conservation bench terrace and conventional systems in a sub-humid climate of India. Resour Conserv Recycl 98:30-40. https://doi.org/10.1016/j.resconrec. 2015.03.004

Van Dijk AIJM, Bruijnzeel LA (2003) Terrace erosion and sediment transport model: a new tool for soil conservation planning in bench-terraced steeplands. Environ Model Softw 18:839-850. https://doi.org/10.1016/S1364-8152(03)00084-7

Wheaton, R.Z., and Monke, E.J. (2001). Terracing as a 'best management practice' for controlling erosion and protecting water quality. Agricultural engineering 114, Purdue University. Available: http:// www.agcom.purdue.edu/AgCom/Pubs/AE/AE-114.html. Accessed 27 July 2018

Wymann von Dach, S., Romeo, R., Vita, A., Wurzinger, M., and Kohler, T. (eds). (2013). Mountain farming is family farming: a contribution from mountain areas to the International Year of Family Farming 2014. p. 38, 102. Rome, Italy: FAO, CDE, BOKU

Publisher's note Springer Nature remains neutral with regard to jurisdictional claims in published maps and institutional affiliations. 